\title{
Public librarians and information literacy education: views from Mpumalanga Province
}

\author{
Genevieve Hart ' \\ Department of Library \& Information Science, University of the Western Cape \\ ghart@uwc.ac.za
}

\begin{abstract}
Accepted: $7^{\text {th }}$ August 2006
The paper reports on one part of a questionnaire/interview survey of 57 public librarians, conducted in Mpumalanga Province in 2004 to assess the readiness of public libraries for information literacy education - specifically, given the shortage of school libraries, that of their school learner users. It analyses the data gathered in a group of open-ended and Likert-scale questions that probe staff perceptions - in the belief that these subjective factors are crucial to sustainable programmes. The study attests to the pressures on South African public librarians, who feel unprepared for a teaching role. Three themes are explored: respondents' understanding of the concepts of information literacy; respondents' own information literacy; and their views on the role of public libraries in information literacy education. Restricted conceptions of information literacy are found to limit the role of public libraries in the learning process of information literacy, with the prevailing notion of service being the 'giving' and 'fetching' of information on demand. The study finds ambivalence towards an enhanced educational role for public libraries - caused by contradictions between the heavy daily demands of learners and beliefs about the proper role of a public library.
\end{abstract}

Keywords: Information literacy education; public librarians; South Africa; Mpumalanga Province

\section{Introduction}

The paper reports on one part of a research project which explores the capacity of public libraries in South Africa for information literacy education - specifically that of school pupils or learners. A representative sample of 46 public library sites in the rural province of Mpumalanga was visited and 57 members of their staff were interviewed in March 2004. The questionnaire/interviews gathered data on staffing, usage statistics, information literacy resources in the libraries, existing information literacy programmes, relations with schools and librarians' views on their role in information literacy education and, indeed, in the school curriculum. The focus in this paper is on this last subjective factor - examined in several questions in one section of the questionnaire/interview.

In keeping with the tenets of interpretive constructivism (Dick, 1993), the premise of the study is that sustainable information literacy education in public libraries must rest on insight into how the phenomenon of information literacy is interpreted by the people responsible for its implementation.

\section{Rationale}

Another underlying premise of the project is that South African public librarians have to take enhanced responsibility for information literacy education, and, indeed, for formal education in general, which, in some other countries, might be assumed to be the specific mission of school librarians. Less than $30 \%$ of South African schools have libraries (South Africa. Department of Education 1999). Educational reform in post-apartheid South Africa has resulted in a shift from rote-learning from textbooks towards resource-based learning and continuous assessment by means of portfolios and projects (South Africa. Department of Education 2002; Lombo 2002).

Some research has supported the comment at librarians' conferences that the new curriculum, widely known as Curriculum 2005, coupled with the shortage of school libraries, has brought an increase in pupils' use of public libraries (Shaw 2000; Maepa \& Mhinga 2003; Hart 2004). In 1999, the author found unanimity among 67 children's librarians in Cape Town that the new curriculum was responsible for the increase in use of their libraries by learners (1999). A later study in two public libraries in a disadvantaged township in Cape Town documents the high numbers - with over 900 being interviewed over four afternoons (Hart 2004). The most common reason for their visit to the library on the day of the interview was to 'do a project'. Rural libraries might well be experiencing the most intense pressure, since rural schools are the least equipped in terms of libraries and learning support materials (Bot 2005). Nkosi (2000: 260) gives a glimpse of the pressures when she reports a comment from a rural public librarian in the Eastern Cape that on some afternoons children sit on the library's doorstep crying to be admitted.

The evidently increased responsibility for information literacy education among public libraries puts the spotlight on their capacity for this role. It might well imply a fundamental shift - a 'metamorphosis from librarian to educator'

I. Genevieve Hart (PhD) is Senior Lecturer and Chairperson of the Department of Library and Information Science, University of the Western Cape, South Africa 
(Peacock 200I: 27). However, the capacity of librarians for teaching has been questioned (Peacock 200I; Bruce \& Lampson 2002; Clyde 2002). Capacity might be defined at two levels:

- physical resources - including adequate space, adequate staffing, teaching resources, and information retrieval tools, such as catalogues and indexes, with which to learn information literacy skills

- more subjective factors which perhaps might be encapsulated in the word 'will'. Public librarians' will to take on a more directly educational role must be influenced by factors such as knowledge of information literacy, knowledge of the curriculum and beliefs about the mission of public libraries.

The focus in this paper is on the second level. Its purpose is to describe and analyse the data which throw light on respondents' attitudes towards the increased use of public libraries by school learners and towards their role in information literacy education. The rationale is that these subjective factors might well be crucial in the building of sustainable information literacy education that meets the needs of South African school learners.

\section{Information literacy education}

The research of two influential theoreticians in the field of information literacy, Carole Kuhlthau and Christine Bruce, scaffold the study. Both agree that information literacy has to be viewed within the framework of learning theory.

Kuhlthau's research in schools and universities since the early 1980s has led her to see information literacy as a constructivist lifelong learning process in which information users build personal meaning and knowledge out of uncertainty (2004). The outcome of her research is the Information Search Process (ISP) model, which depicts the thinking, behaviours and emotions of the various phases of information seeking. Information literate people are able to negotiate the phases - tolerating the early stages of uncertainty and filling in background knowledge until they find a personal focus and formulate questions which will guide their information search. To Kuhlthau, information literacy is not about finding the right answers but about using information to learn (2000).

Bruce draws on relational learning theory in her groundbreaking phenomenographic study of Australian academics' conceptions of information literacy. Its outcome is a diagram that identifies seven categories and their interconnections. Bruce groups the categories into three clusters:

- the information technology (IT) and information sources conceptions

- the information process and information control conceptions

- the knowledge construction, knowledge extension and wisdom conceptions. The use of IT or any other resources is incidental. What matters is the role of information in transforming existing conceptions, creating new knowledge and, ultimately, building wisdom (1997: 173).

Some conceptions are clearly more 'complete' than others. Thus, conceptions in the third cluster 'contain' those in the first and second clusters. Bruce contends that a complete information literacy programme needs to operate across all three groupings.

A perusal of the literature reveals the influence of the theory-building research of Kuhlthau and Bruce. On the ground, the construct of information literacy education has meant a move away from the traditional source-based library instruction or bibliographic instruction, in which the emphasis is on reference tools in the library. Effective information literacy education requires a process approach in which information seekers learn to see information seeking and handling as a problem-solving and constructive learning process, consisting of several (non-linear) phases, each of which demands its own strategies. Learners learn when a specific tool might be useful and why - applying the instruction to their own needs. Loertscher and Woolls provide a useful overview of these trends, showing how popular models, like the Big Six, embed their instruction within school assignments, teaching the information skills and tools that are required at each stage from analysing the topic to writing-up (2002).

The process approach to information literacy implies that its assessment is rather complex. The models for the Mpumalanga study are the approaches which assess levels or completeness of respondents' information literacy in terms of awareness of information seeking as a cognitive process of interdependent phases. Some of these studies use process models to assess how respondents tackle assignments, solve information problems or describe critical incidents (for example Todd 1995; Moore 1998; Byron \& Young 2000; Branch 2003; Stilwell \& Bell 2003). The premise in this research is that people who are conscious of the phases and strategies of the information process are more likely to be information literate.

Previous research in librarians' views

There has been only limited research in the views of the people arguably at the centre of information literacy programmes - library staff. The research, moreover, seems to be largely within academic and school librarianship.

The context for the discussion of information literacy education in public libraries is often the need for an information literate citizenry, able to cope with the demands of the information and communications technologies (ICT) of the global information economy (Todd and Tedd 2000; Bundy 2002a). When people use public library facilities to access the 
Internet, the question of their computer competencies arises, and of whose responsibility it is to provide training. Julien and Breu's study of instructional practices in Canadian public libraries sees public libraries as agents in the government's Connecting Canadians project 'to make Canada the most connected country in the world' (2005: 28I). While 85\% of their 152 public librarian respondents believe that information literacy education is a responsibility of public libraries, and $93 \%$ believe that children need information literacy training, $41 \%$ claim that public library staff are unprepared for such a teaching role. The three most cited barriers are inadequate training, time constraints and shortages of staff.

Bruce and Lampson's investigation of more than 2000 information professionals in the State of Washington, USA, includes 800 public librarians. They find widespread unease with regard to teaching (2002: 103). There are significant differences between the public library respondents and others, with, for example, public librarians reporting less exposure to information literacy education in their university education. Perhaps it is this gap that explains another distinguishing characteristic of the public library respondents - their belief that information literacy education is not needed in public libraries since it is the job of the librarian to serve their clients and find information for them. The study lends support to Curran's suggestion that the domain of information literacy might well be new territory for public librarians, many of whom, he contends, tend to see information as a 'utility' - a commodity, which they organise and hand out to their clients (1990: 35I).

The preliminary investigation of the LIANZA Taskforce into Information Literacy in New Zealand's libraries suggests that public librarians are less likely to see information literacy in a broad societal context than other librarians. They are more likely to emphasise information technology skills in their definitions, for example, and so to place it within the province of more technologically advanced sectors - like school and academic libraries (LIANZA Information Literacy Taskforce 1999). The report of the follow-up study on information literacy education in public libraries in New Zealand recommends changes 'in staff awareness, attitudes and skills' (Koning 200 I). It raises the following issues:

- prevailing doubt over a teaching role for the library

- librarians' preconceptions of what they do and do not do

- understandings of the difference between library skills instruction and the broader learning of information literacy education, called 'research skills' in the report.

Noting the increase in pupils' use of Australian public libraries, in 200 I Bundy investigated school/library connections in a survey of 1496 public librarians and 2325 school librarians. Among the factors he identifies as significant to effective collaboration is acceptance by public library staff that co-operation is a longstanding role for public libraries and that relations are often informal. He suggests that the 'shared endeavour' of information literacy education demands an end to the professional insularity he found among the librarians in both sectors (2002b: 68).

\section{Mpumalanga study}

The brief survey of research holds several implications for the study in Mpumalanga, for example:

- Bruce's research suggests that the 'completeness' of information literacy educators' conceptions of information literacy have to be examined, as they will impact on the nature of the information literacy programming they plan.

- The emphasis in current thinking on the process of effective information seeking means that librarians teaching information literacy cannot restrict their instruction to one phase. Successful information retrieval in the library or on the World Wide Web, for example, depends on insight into the subject and on the successful formulation of authentic questions (Branch 2003).

- This last point implies that information literacy educators cannot work in isolation. Partnerships are crucial.

- Librarians' beliefs about the educational role of libraries and their own capacity for information literacy education must impact on library information literacy programmes and therefore need to be understood.

The choice of Mpumalanga as research site came out of a conversation with the Director of Mpumalanga Provincial Library Service, who expressed a desire to develop information literacy programmes in his province and to know more about public library capacity for them. Mpumalanga's social and economic characteristics throw into relief the challenges that confront public libraries in South Africa. In common with other South African provinces, Mpumalanga's public libraries are unevenly distributed (Van Helden \& Lor 2002) - with its rural areas in need of 98 new libraries, according to the Director (Hendrikz \& Smit 2003). Only 18 percent of its schools have libraries (Bot 2005).

\section{Methodology}

Interviews were conducted in 46 libraries - comprising a representative mix of sites that were chosen first by their geographic position in the six regions of the Mpumalanga Provincial Library Service. Other factors in the choice were the size of library (large and small) and position in historically advantaged (white) and historically disadvantaged (black) 
communities. The final stratified sample included 23 sites in historically white areas and 23 in townships or rural settlements in Mpumalanga's two ex-'homelands'.

Apart from the sampling of sites, choices over interviewees within the sites had to be made. Fifty-seven people were interviewed out of a possible total staff complement in all 46 sites of I 37 . The sampling frame consisted of the librarian-incharge plus staff involved in the information literacy education of school learners. The plan was to interview the senior staff member in charge and at least one other staff member who might be a decision-maker with regard to services to schools and information literacy education to children and learners.

As Moore (1999: 12I) points out, semi-structured interviews are a 'halfway house' between the formality of a structured survey and the flexibility of a depth interview. Powell's comment (1997: I 16) that personal interviews allow for 'low education levels' is germane, as respondents could not be assumed to have had much exposure to the concept of information literacy. The concept of information literacy has received more attention in educational library circles than in public libraries. Moreover, formal professional qualifications could not be assumed. Another consideration was the need to negotiate language barriers. Only six respondents were first language English speakers.

Section $C$ of the questionnaire/interview, headed 'Perceptions of information literacy', is the focus of this paper. The aim in Section $C$ is to uncover some of the subjective factors that underlie information literacy programmes in public libraries. Its 10 open-ended questions and Likert scale questions explore the following:

- respondents' familiarity with and understanding of the concepts of information literacy and information literacy education

- respondents' own information literacy

- their views on the role of public libraries in information literacy education.

The mix of question type in Section C, open and Likert-scale, is designed to gather both quantitative and qualitative data - and thus to elicit nuanced responses. Open-ended questions can at times reveal more about deeply-held beliefs and attitudes, as they catch people more unawares and allow for broader in-depth answers. There is some returning to topics as this kind of redundancy might serve to confirm or contradict tentative findings.

All interviews were recorded and transcribed. Quantitative data were summarised and analysed by means of Excel spreadsheets. Qualitative data were analysed for connecting threads of thought or 'units of meaning', and tabulated. Restrictions of space do not allow for the full tables with the units of meaning and supporting quotations to be displayed in this article. Only summaries and a limited number of direct quotations can be provided.

The demographics of the 57 respondents, chosen for their role in the information literacy programmes of their libraries, are summarised below:

- Fifty respondents are female; seven are male.

- The mean age is 39 years.

- The average number of years in their present library is six years - with seven years being the median.

- Nine of South Africa's official languages are represented - with Zulu-, Afrikaans- and SisWati- speaking respondents making up 39 out of the total of 57.

- Twenty-two respondents are the sole member of their library's staff. The 22 one-person sites are evenly split between historically white and historically black areas.

- Seventeen (30\%) have tertiary qualifications (mostly a diploma or degree in Library and Information Science); $47 \%$ have Matric; $18 \%$ lack Matric. Fourteen librarians-in-charge have professional librarianship qualifications, a degree or diploma. Only four librarians in charge of libraries in historically disadvantaged communities have professional qualifications, however; and six librarians in charge of township libraries do not have Matric.

- Only one respondent reports that his university degree included the construct of information literacy education.

\section{Discussion of findings}

This section analyses and, to some extent, interprets the data gathered on the views of the Mpumalanga public library staff on information literacy, information literacy education and their educational role. 'Views' is an intentionally umbrella term, at various times denoting opinions, attitudes, beliefs, perceptions and conceptions.

Earlier questions in the interview schedule, reported on elsewhere (Hart 2006), reveal information literacy education in Mpumalanga's libraries to consist mostly of once-off library orientation, in which classes are introduced to the library at the beginning of the school year or during the annual Library Week, and of one-to-one support in the busy afternoons. The questions that probe public librarians' current experiences confirm the strand of comment in the South African professional literature on the impact of Curriculum 2005 that was referred to earlier. Fifty-four respondents believe that Curriculum 2005 has brought an increase in the numbers of learners in their library. Explanations for the increase in use are summarised as follows:

- South Africa's new curriculum requires learners to use more library resources.

SA JnI Libs \& Info Sci 2006, 72(3) 
- The end of apartheid education has meant that black children now have the same demands made of them as white.

- Schools do not have adequate resources.

- Most South African families cannot afford to buy books or access the Internet.

- Public libraries are now more welcoming to black users.

These two quotations provide insight into the challenges:

OBE [Outcomes based education] wants current topics. It's difficult to cope. Kids have to learn themselves; he has to do everything by himself. The parent does it! White parents and Indian that is - Black parents are working. Kids themselves don't know what they're looking for. Before OBE everything was on the syllabus. Everything is so recent, we don't have that information. (Questionnaire 35)

Previously they didn't even bother to come. Now they don't have a choice. Now the curriculum is channelling them to the library. That is why l'm wondering why government is not resourcing school libraries. Resources should have come first, then implement Curriculum 2005. They should have started with resources. I don't know what government was thinking. (Q53)

The comments on relationships with educators are often ambiguous. Many begin with a polite comment, which is immediately qualified, for example:

Not a problem. They don't come to tell us their projects. Is it my duty to go and ask them? (Q46)

It's a good relationship. Although most don't encourage the children to come to the library. (Q28)

The rhetorical question, in the first quotation, 'Is it my duty to go and ask them?' indicates a certain irritation, which is echoed by others.

Many respondents acknowledge that they do not know how to support learners in the library, who, all agree, are illprepared. A common comment is that students do not understand their project topics. Perhaps this is why the librarians feel that they have to give them the information required. For example:

Sometimes, I'm the one doing the project from A to Z. (Q5)

They ask me, 'Tannie, waar moet ek lees?' [Auntie, where must I read?] (QI)

The insight into how respondents experience their work with school educators and learners serves to lead into the discussion of findings in this section. The Section explores three themes:

- conceptions of information literacy and information literacy education

- respondents' information literacy

- perceptions of the role of public libraries in information literacy education.

Conceptions of information literacy and information literacy education

The first few questions in Section C challenge participants to articulate theoretical knowledge of information literacy and information literacy education. The word 'conception' is often used specifically within the context of phenomenographic research, such as Bruce's study, mentioned above (1997). While the insights on information literacy education that come from Bruce's diagrams of conceptions of information literacy inform the study in Mpumalanga, the term is used in this paper in its commonplace meaning of 'understanding'.

On being asked to describe an information literate person in a preliminary open-ended question, the majority of respondents mention just two attributes:

- the ability to use the library and its resources, as illustrated in the answers :

They know how to use library (Questionnaire 17)

He knows the difference between encyclopaedias, dictionaries and atlases (Questionnaire 28)

- the ability to find information in general, for example:

They will find information even if not in the library (Q3)

They know how to get it (Q36)

A person who can help himself. Can get the information he needs (Q39)

Just one respondent showed awareness of the power of information in the process of learning, saying:

It's having the tools and skills to help herself find information, change perceptions, change knowledge and gain knowledge by it (Q16)

One noteworthy gap is that no respondent mentions the ability to assess information.

The preference for words that betray a conception of information as, in Curran's term, a 'utility' (1990), suggests that respondents largely belong within Bruce's first cluster mentioned above. They are preoccupied with sources, seeing information as something that is fetched or 'got' and that librarians store and 'give'. Kuhlthau's distinction between 
information literacy as a cognitive 'process' and approaches that see it in terms of 'getting' the right answer in a source is pertinent here (2000).

The next question, Question 16, continues the exploration of conceptions of information literacy, presenting a number of Likert-scale statements for five categories of response. Figure I summarises the responses - sorted in order of agreement from least positive agreement to most.

\section{Agreement With Statements About Information Literacy}

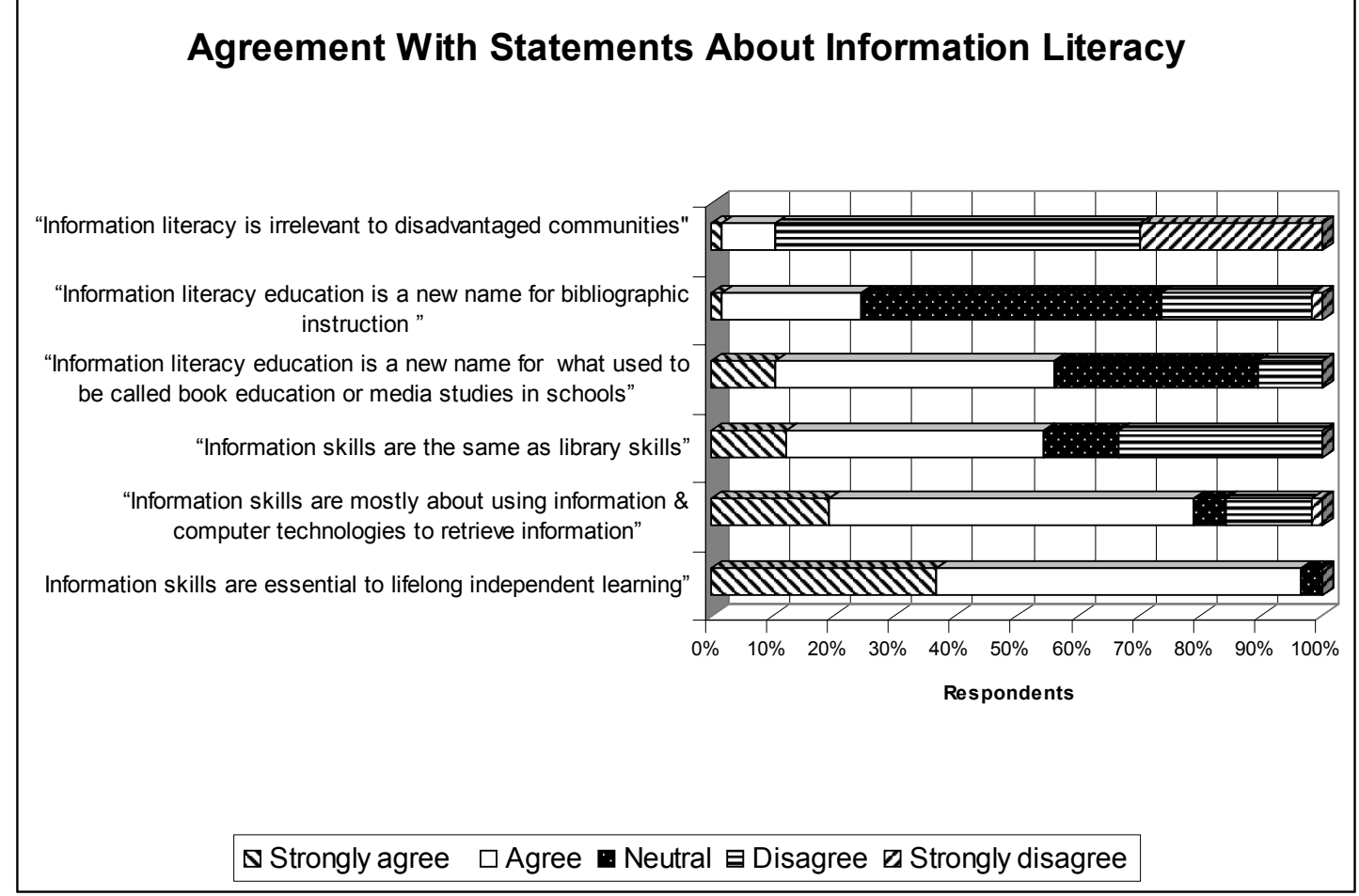

Figure I Agreement with Statements on Information Literacy (Question I6)

The responses to the first statement in Figure I show the strong agreement that information literacy education does not belong to advantaged communities only. The next three statements in Figure I probe perceptions of information literacy in relation to other terms. The high number of 'neutrals' for the second statement suggests that the term 'bibliographic instruction' is not familiar - and, indeed, it is a term mostly used in academic library circles. There is some identification of information literacy with 'book education', the subject in the South African curriculum in the 1970s. It is perhaps further evidence that many respondents' conceptions of information literacy belong in Bruce's first cluster of conceptions. They, thus, see information literacy in terms of 'getting' information from sources with frequent mentions of encyclopaedias, dictionaries, and non-fiction.

In the preceding open-ended question very few mention ICT; yet responses to Question 16 shows 44 respondents in agreement (with $2 \mathrm{I}$ of these in 'strong agreement') that information literacy involves ICT. The identification of information literacy with ICT is a potential barrier to the acceptance of the value of information literacy education. If information literacy is seen as dependent on ICT, then people working in less privileged environments might dismiss it as irrelevant and unattainable (Moore 2002: 4). The last statement in Figure I shows the virtual unanimity that information skills are essential to lifelong learning - an encouraging sign for any future information literacy programming in the Province.

The next open question, Question 17, pursues this issue in asking respondents to articulate connections between information literacy and lifelong learning. The resulting tabulation of responses yields the following findings, given in order of frequency of response from most common to least and with supporting quotations:

- Libraries teach information literacy and therefore are crucial in lifelong learning. Typical responses in this category include:

The information you get from the library will help in your lifelong learning. It starts there - you'll keep them [skills] \& build on them (Q8)

Library skills are lifelong learning (Q28)

- Without information literacy, people cannot be lifelong learners:

They go hand in hand. To have lifelong learning you need information literacy (QII) 
Because if you don't have information literacy, you can't learn (Q35)

- Information literacy is about information retrieval skills - skills that will last for life:

You're supposed to be able to retrieve information, otherwise you can't go on learning (Q9)

Maybe you don't know how to cook spaghetti, if you're information literate you'll find out how - with a recipe book or ask someone (Q25)

- Information literacy is needed for furthering formal education - at tertiary level and in continuing professional development.

For further studies, you'll use information literacy for retrieving information (Q44)

I want to learn \& learn. I want to be City Librarian. I started as a cleaner at the beginning. Now I'm Assistant Librarian (Q45)

Again, respondents reveal their orientation towards libraries - with the most common responses linking libraries to information literacy and then to lifelong learning.

Nonetheless, perhaps what is most noticeable in the responses to the question on lifelong learning is the stronger recognition of the skills of information literacy - perhaps edging closer to Bruce's second cluster of conceptions. More respondents convey a dynamic picture of what use of the library and its information resources demands and how it empowers people in their everyday lives, with some comments reminiscent of the adage that it is better to teach people how to fish than give them fish. According to Cronau (200I), such positive attitudes towards what she calls library 'customer education' are a pre-requisite for effective information literacy education that contributes to lifelong learning.

Respondents' information literacy

Question 24 addresses respondents' personal information literacy. It disguises its intention by asking respondents to describe the steps a school learner might go through in tackling the school project 'Culling Elephants in the Kruger National Park'. Respondents' own information literacy should be reflected in their descriptions of what they expect of school learners. The answers to the question were analysed according to a template of seven phases, borrowed from information literacy process models, such as Kuhlthau's ISP:

I. Analysing the need - or topic

2. Recognising need for background knowledge to find a personal 'angle'

3. Deciding where to go

4. Finding relevant information

5. Engaging with information, reading, summarising

6. Synthesising information from different sources

7. Organising information, presenting it, writing it up.

Figure 2 is the result of the analysis of responses to the question. It is sequenced by total number of blocks or stages in one respondent's answer, ranging from answers that made no coherent mention of any phase to those that mentioned six. The Figure serves horizontally to record the sophistication of each response in terms of number of phases referred to and, vertically, to show which stages receive the most mentions. Fifty responses are represented - several being too incoherent to include.

Figure 2 confirms the findings of earlier questions - namely, that, in common with Bruce and Lampson's American public librarian respondents (2002: 85), the Mpumalanga participants are pre-occupied with finding skills. Stages 3 and 4 receive by far the most mentions ( 39 and 25 respectively). In fact, often the 'finding' is described rather as 'fetching' with little emphasis on the evaluative and problem-solving skills of searching. Seventeen describe the first step as 'asking the librarian for' the information needed. The next most cited stage is the first - 20 respondents alluding to the importance of understanding the need for information before the focused search begins. Only eight respondents refer to Stage 5, synthesising information from different sources, and only four the seventh stage, organising the gathered information. The frequent references to 'photocopying' suggest that respondents feel that their job is done once they hand the child the page. Thus, children are described in some answers as finding the information and photocopying it and then going home.

Only four show some kind of awareness of the need for learners to see the bigger picture before they focus on finding information for the specific topic. They talk of 'having a mental picture' (Questionnaire 10), 'identifying the problem' (Questionnaire 22), and 'having questions ready' (Questionnaire 49). This last quotation perhaps hints at Doyle's contention that, in the information society, 'Knowing how to ask the right questions may be the most important step in learning' (1999: 99). Branch describes the finding of an essential question as the 'hardest part of any inquiry' (2003: 37). The lack of insight into Stage 2 in Mpumalanga libraries might mean that children are given information before they are ready for it. The Australian researcher, Todd, contends that 'all too often', children fail to build genuine new understanding because they are not allowed enough time for reflecting and formulating while they explore and collect information (2004: 35). 


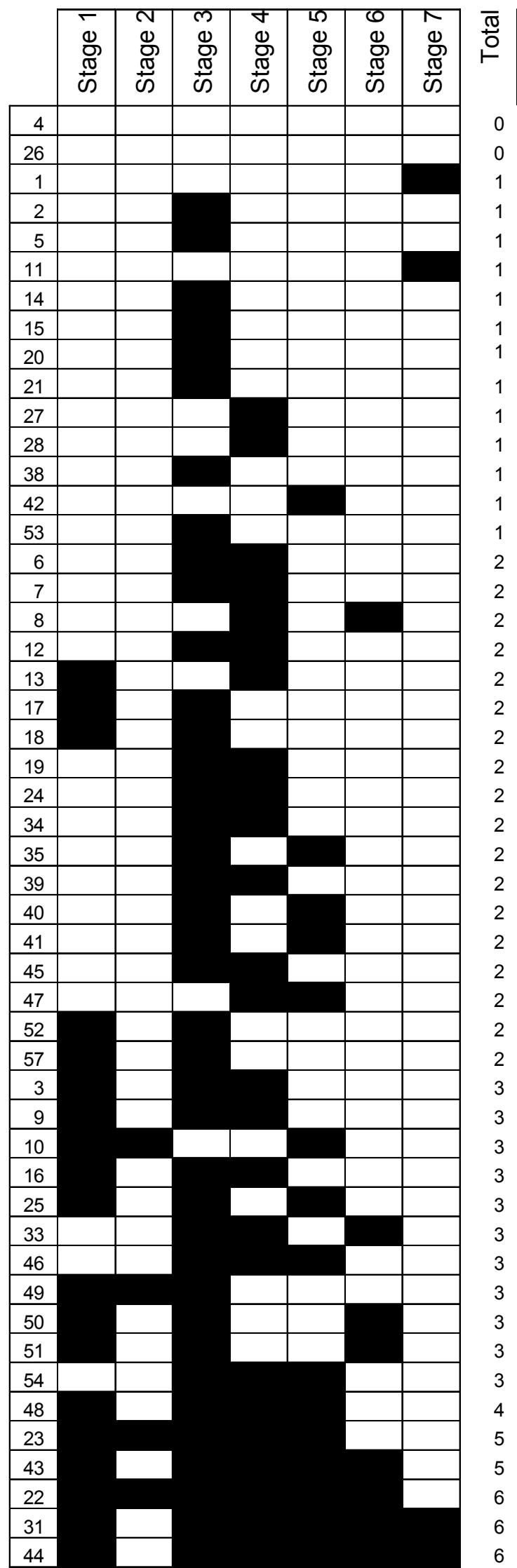

\section{Stages}

1. Analysing need

2. Recognising need for background knowledge

3. Deciding where to go

4. Finding relevant information

5. Engaging with information, reading, summarising

6. Synthesising information from different sources

7. Organising information, presenting, writing up

Figure 2 Awareness of Stages in Information Seeking Process (Question 24) 
The evident pre-occupation with the finding stage, especially if 'finding' really means 'fetching' and 'giving', when viewed in the light of information literacy theory and previous research, has two implications:

- respondents might have rather limited insight into what makes up information literacy

- their own incomplete levels of information literacy might limit their view of information literacy education.

Restricted views might allow librarians to distance themselves from the pedagogical issues of whether children understand the concepts they are 'researching' and what they do with the bits of information found for them by library staff. Curran, in 1990, claimed that "it is in the area of "information use" - of interpretation, organization, and communication - where even less connection with the library has been established either by us librarians or by users and non-users' (1990: 35I). The following section focuses on respondents' perceptions of their educational role and so will expand this discussion.

Perceptions of the role of public libraries in education \& information literacy education

Three questions uncover the beliefs about the social mission of public libraries. The Likert-scale Question 18 includes five philosophical statements on the educational role of public libraries and three that probe respondents' perceptions of their preparedness for a teaching role. Figure 3 summarises the responses, in order of least to most agreement with the statements.

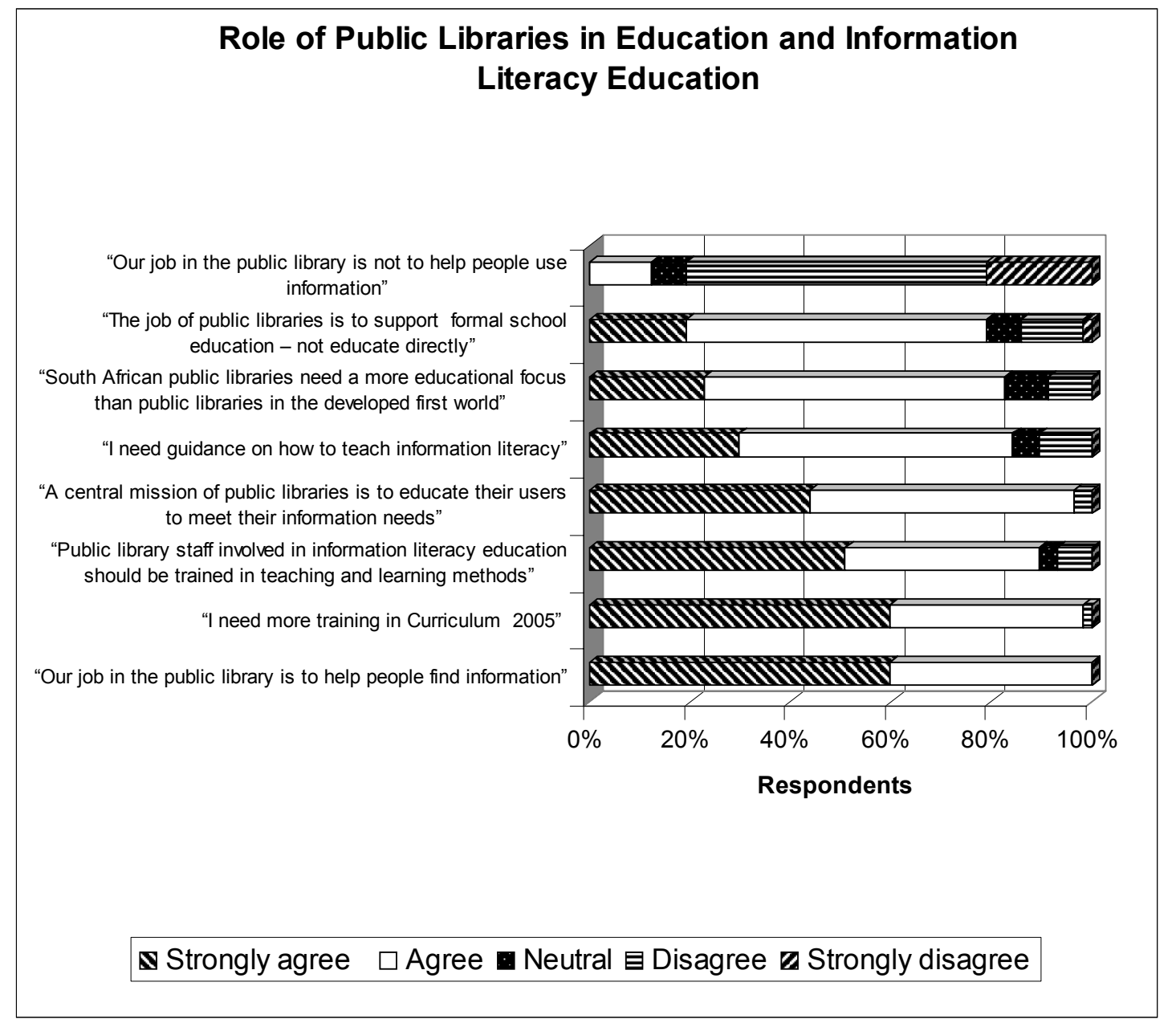

Figure 3 Agreement with Statements on the Role of Public Libraries in Education and Information Literacy Education (Question 18)

At first sight, Figure 3 shows little sharp divergence within responses to individual statements, but the shades in agreement between mere agreement and strong agreement might well be significant. Overall, there is acceptance that public libraries in South Africa have a strongly educational role, but there is some ambivalence, evidenced in the accompanying comments. The most positive reply comes from the first interviewee, a young black librarian in charge of a large town library, who pins the future of public libraries on their role in education, saying as she replies to the last statement in Figure 3:

Our educational role will ensure our continuing existence. (QI) 
Responses to the second statement in Figure 3 seem to contradict other responses. Thus, a strong majority (45 out of a total of 56 respondents) agree that public libraries should play a 'supportive' rather than 'direct' role in formal education. Yet, the next two statements in the figure show that equally strong majorities agree that South African public libraries need a more educational focus than those in developed countries.

Two other statements are designed to probe respondents' willingness to assume a more dynamic responsibility for information literacy education by seeing if they draw a line between helping users find information and helping them use the information. There is some difference in the responses to the two statements. All 57 agree with the non-contentious statement that that their job is to help people find information, with 34 'strongly agreeing'. Only II refuse to support the contention that it is not their job to do more than help users find information - but this time only 12 seem to have strong feelings that it is indeed their job to do more.

Figure 3 shows virtual unanimity on the need for more education in Curriculum 2005 and in learning and teaching methods; however, several hesitate in answering these questions and add some provisos. An example is the respondent who replies thus:

I'd like to be trained [in learning and teaching methods] but not because I want to assist in people learning - I won't have time for it. All I have to do now is use the index, open up the page ... but I still have to give them the right paragraph. ... If someone wants it but doesn't expect it, l'd find the time.(QI5)

Her description of the helplessness of her clients, which obliges her to 'give' them the 'right paragraph', betrays an awareness of the need for information literacy education. Her dilemma is perhaps that, fundamentally, she does not believe that she should be teaching children the skills they lack. Her repeated use of the words 'have to' is interesting. She seems to draw a line between finding the right page for the client and giving any further support. But she then implies that she has no choice because the users just cannot do it by themselves.

The shades in agreement between 'agreement' and 'strong agreement' within the broad agreements evident in Figure 3 might be telling, especially in the light of some of the informal comments accompanying the replies. They suggest that other respondents share this respondent's dilemma. For example the statement, 'The job of public libraries is to support formal school education - not educate directly', elicits broad agreement but with only 10 expressing 'strong agreement'. Together with the doubts evident in the following sample of accompanying comments, this indicates an acknowledgment that they are in fact involved directly in the school curriculum, for example:

But schools don't have teacher-librarians and we have to do it. It shouldn't be our job but for a myriad of reasons it's the reality. (Q43)

We have a lot of black kids and first time users - therefore we play a direct role. (Q37)

At the moment we are doing it directly but we are not supposed to. We should be serving all groups - not just the schools. (Q4)

Replies to the statement, 'South African public libraries need a more educational focus than public libraries in the developed world', show broad agreement. The agreement, however, might be rather reluctant, as 34 'agree' rather than 'strongly agree' and even those in agreement reveal their ambivalence in the following accompanying provisos:

But OBE (Outcomes Based Education) fell on us - it was chaos. (Q3)

It's true in a way but it shouldn't be the norm. (Q7)

The preceding two sets of comments express similar thoughts, even though they are in response to statements offering different stances. The informal provisos and second thoughts that follow the Likert-scale answers thus serve to throw light on the contradictions in Figure 3. They suggest that respondents might be caught between the reality on the ground and their long-held beliefs on the role of the public library.

A perusal of replies to the following open question, Question 19, might further aid interpretation of Figure 3. It simply asks respondents to comment on the educational role of the public library. An examination of the words chosen by respondents and the resulting tabulation of units of meaning show that many respondents use the question to return to the focused statements of the preceding Likert-scale question to follow up trains of thought, thus:

- Public librarians struggle with school learners who come to the library lacking the required information or library skills. Examples of these kinds of comments are:

In the first place they can't say to you what it is they are looking for. They say 'We are looking for fishes' \& we say 'What about fishes?...' You find a book \& you know the information is in there but they want us to read the pages \& say 'Question I - there is the answer. Question 2 - there is the answer'. (Q3) 
When we ask 'What is your assignment?' we see it as a practical problem - they don't see this. We have to explain it. Directions are not given in class. They just want a book to copy from. (Q46)

- Libraries have new kinds of users - whose background has not prepared them for library use:

Black communities didn't have libraries - never had libraries before, never needed them. It's the first time, some now enter. (Q4)

- Public librarians are subject to conflicting demands. Some see this as a tension between their 'proper' role and the new one that has landed on them without preparation:

Five years ago everything changed. But we are supposed to serve all communities. We're supposed to be a public library - everything changed five years ago (QII)

Public library must be open for everyone - not specifically for education - it's for all. If we become specific for education - schools have their own library. (Q25)

- The capacity of public librarians for teaching is questioned. Can they be expected to be teachers? In Curriculum 2005 most learners need independent research, not dependent on teachers. Some librarians did not do Curriculum 2005, therefore we need training. (Q10)

We act like teachers - need to know how to help. Are we doing it right? (QI4)

- Public libraries lack capacity for information literacy education in terms of space and stock:

If they [Education Department authorities] can help us with books, especially [to do] with this millennium. Kids are looking for information on things happening now - our books can't cope. (Q38)

Some of the responses to the open question support the suggestion above that the contradiction in Figure 3, between respondents' stated belief that public libraries should play only a supportive role in education and their evident desire, for example, for education in Curriculum 2005, might come from a gap between experience on the ground and the received wisdom from traditional public librarianship. The frequent use of words like 'should', 'must' 'supposed to' in the responses to these two questions implies a dilemma. It seems that they are torn between how things should be, according to their long-held beliefs, and how things are in reality. As mentioned in an earlier section, Koning (200I) finds similar preconceptions to affect New Zealand's public librarians' attitudes to their services to school learners.

The strands of comment on changes in users and conflicting demands suggest a shift in the mission of South African public libraries. It seems that the demands of learners and students are taking precedence over the needs of more traditional user groups - adult leisure readers, for example. Some regret is evident among librarians who believe that leisure reading is being neglected. Some reveal a kind of stoic acceptance, thus:

We won't be able to get away from the educational side of it. We shall have to accept it. (Q46)

However, some librarians, perhaps the younger black professionals, welcome the change, with one saying:

If we are hectic, then so be it! (QI7)

It seems that, whatever their personal feelings about the changes, all agree that they are experiencing pressure on their services and that they lack capacity to cope with learners' demands.

\section{Conclusions}

This paper has isolated one component of the Mpumalanga study in the belief that participants' views on information, information literacy and the educational role of public libraries are the most crucial factor in any future planning of information literacy programmes. The last question in the questionnaire/interview asks for any concluding comment on the role of the public library in education. Respondents choose to return to themes, anxious to reiterate the things they feel strongly about. In keeping with the constructivist belief that the central aim of research is to provide insight into participants' experienced realities, the responses might serve to conclude this paper.

Many return to the impact of educational change on the libraries, with some ambivalence evident as in the comment:

Five years ago we thought public libraries would die - the use had changed so much. Our job is much more difficult -

we are giving class. There's much more tension than the old days. It's very different our job from when I started. (Q4)

In common with Canadian public librarians (Julien \& Breu 2005), respondents report a lack of preparedness in terms of training and resources - space, time and staff. Indeed, the study suggests that the low level of education of public library staff might impede innovation. Information literacy education demands insight into constructivist learning and contemporary pedagogies - as well as into the attributes and tools of the information society.

It seems that 'incomplete' conceptions of information literacy might restrict the role of public libraries in the learning process of information literacy. Respondents draw clear lines around their public library work. Whether they accept their part in the 'information literacy chain' (Curran 1990: 35I) of interpreting, synthesising, using and communicating 
information is questionable. The language used in the comments on educators indicates a preoccupation with telling educators about 'how libraries work' rather than a desire to be involved as a partner in the learning process. There is, at the same time, however, dawning recognition that present approaches are not meeting the needs of school learners and that more effective communication with educators is required. This recognition comes, however, from public librarians' frustrating encounters with learners rather than from insight into the interdependence of the phases of information seeking.

A few express anger at changes in local authorities' structures. For example, a librarian, who used to run the library of a small town that has now being absorbed into a large local municipality, clearly resents her loss of autonomy:

If it was before I would elaborate [on the question]. But now I must stay inside, they say. I am feeling frustrated. Instead of going forward I'm going backwards. I used to attend meetings so was aware of what was going on outside.

I daren't raise the issue - l'll be accused of being political. (Q5)

The accompanying wish for more recognition is a strong thread:

I think in the past 10 years public libraries have been in a bad situation - left behind by the province and our municipality. I think it's time the public library gets the attention again they deserve. (Q3)

We can do more but we don't get support. Our directors - not one - have been inside the library in the last four years. Our manager applied for membership - he used it once or twice. (Q8)

Such comments betray a sense of isolation. Moving from the prevailing library orientation towards information literacy education will depend on a shift in conceptions of the educational role of public libraries. In the absence of recognition of their curricular role by public library authorities and educationists, many public librarians are not sure that their services to school learners are legitimate. The evidently low morale is a key issue for South African public librarianship. The study indicates that South African public libraries are in a state of transition - perhaps leaving behind the inherited Western models of service. However, in the absence of explicit mission and policy statements and confronted by the huge increase in student use, their staff are unsure what their 'real' mission is.

The author acknowledges the contribution of Mpumalanga's public library staff. All those approached agreed without hesitation to participate in the study.

\section{References}

Bot, M. 2005. School education in South Africa: tracking change over ten years. Edusource data news, 48: I-15.

Branch, J L. 2003. Inquiry takes time: breaking down barriers to an understanding of the inquiry process of grade 9 students. In Zinn, S, Hart G, \& Howe, E. Eds. IASL reports 2003: school libraries breaking down barriers. Selected papers from the 32nd Annual Conference of the International Association of School Librarianship and the 7th International Forum on Research in School Librarianship, Durban, South Africa, 7-II July 2003. Seattle: IASL: 35-42.

Bruce, C. 1997. The seven faces of information literacy. Adelaide: Auslib Press.

Bruce, H. \& Lampson, M. 2002. Information professionals as agents for information literacy. Education for information, 20: 81106.

Bundy, A. 2002a. Enabling the knowledge nation: what Australia needs in the $21^{\text {st }}$ century. Australian library journal, $5 \mathrm{I}(2)$ : $103-$ 116.

Bundy, A. 2002b. Essential connections: school and public libraries for lifelong learning. Australian library journal, 5I(I): 47-70.

Byron, S M \& Young, J I. 2000. Information seeking in a virtual learning environment. Research strategies, 17(4): 257-267.

Clyde, A. 2002. An instructional role for librarians: an overview and content analysis of job advertisements. Australian academic \& research libraries, 3: 150-166.

Cronau, D A. 200I. Lifelong learning and the library connection: a perceptual model for tertiary library customer education. Australian library journal, 50(4): 335-347.

Curran, C. 1990. Information literacy and the public librarian. Public libraries, 29(4): 349-354).

Dick, A. 1993. Three paths to inquiry in library and information science: positivist, constructivist and critical theory approaches. South African journal of library and information science, 61 (2): 53-60.

Doyle, C. 1999. Information literacy in an information society. In Haycock, K. Ed. Foundations for effective school library media programs. Englewood, Colo: Libraries Unlimited: 97-100.

Hart, G. 1999. Ready for the information society? A study of Cape Town's children's librarians. New review of children's literature \& librarianship, 5: 151-169.

Hart, G. 2004. Public libraries in South Africa: agents or victims of educational change? South African journal of libraries and information science, 70 (2): II0-121.

Hart, G. 2006. The information literacy education readiness of public libraries in Mpumalanga Province (South Africa). Libri, 56(I): 48-62.

Hendrikz, F. \& Smit, A. 2003. South Africa: Mpumalanga Provincial Library and Information Service. In Chisenga, J. Ed. The use of ICTs in African public library services: a survey of ten countries in Anglophone Africa. Oxford: INASP: 95- 103.

Julien, H \& Breu, R D. 2005. Instructional practices in Canadian public libraries. Library \& information science research, 27(3): 28I-30I.

Koning, A. 200I. Information literacy in New Zealand public libraries. New Zealand libraries, 49(5): 174- 179.

SA JnI Libs \& Info Sci 2006, 72(3) 
Kuhlthau, C C. 2000. The information search process: a search for meaning rather than answers. Library \& Information Science, 43: $35-42$.

Kuhlthau, C C. 2004. Seeking meaning: a process approach to library and information services. $2^{\text {nd }}$ ed. Westport, CT: Libraries Unlimited.

LIANZA Information Literacy Taskforce. 1999. Progress report to LIANZA Council. [Online]. Available http:// www.lianza.org.nz/literacy.html. Accessed 12 January 2004.

Loertscher, D V \& Woolls, B. 2002. Information literacy: a review of the research: a guide for practitioners and researchers. $2^{\text {nd }}$ ed. San Jose: Hi Willow.

Lombo, S. 2002. The relationship between OBE, learner support materials and a school library. In Education Library Information and Technology Services. Ghost Libraries and Curriculum 2005: [proceedings of] Ist Annual Provincial Conference, I I-I 3 July, 2002. Durban: ELITS, Department of Education and Culture KwaZulu Natal: 3-6.

Maepa, E. \& Mhinga, R. 2003. Integrating a community library into the teaching and learning programme of local schools: experiences from Seshego Community Library, South Africa. In Zinn,S, Hart G, \& Howe, E. Eds. IASL reports 2003: school libraries breaking down barriers. Selected papers from the 32nd Annual Conference of the International Association of School Librarianship and the 7th International Forum on Research in School Librarianship, Durban, South Africa, 7-I I July 2003. Seattle: IASL: 270-279.

Moore, N. 1999. How to do research: the complete guide to designing and managing research projects. $3^{\text {rd }}$ ed. London: Library Association.

Moore, P. 1998. Teaching information problem solving in primary schools. Auckland: Open Polytechnic of New Zealand

Moore, P. 2002. An analysis of information literacy education worldwide. White Paper prepared for UNESCO, the U.S. Commission on Libraries and Information Science and the National Forum on Literacy, for use at the Information Literacy Meeting of Experts, Prague, The Czech Republic. [Online]. Available www.nclis.gov/libinter/infolitconf\&meet/moorefullpaper.pdf $>$. Accessed 12 October 2003.

Nkosi, L P N. 2000. Information provision to black youth in the Eastern Cape province of South Africa. DPhil thesis, University of Wales Aberystwyth.

Peacock, J. 200I. Teaching skills for teaching librarians: postcards from the edge of the educational paradigm. Australian academic \& research libraries, 32(I): 26-42.

Powell, R. 1997. Basic research methods for librarians. 3rd ed. Greenwich, Conn: Ablex.

Shaw, A. 2000. Adolescents as public library users. MLIS thesis, University of Cape Town.

South Africa. Department of Education. 1999. South African school library survey 1999. National report. Pretoria: Department of Education and Human Sciences Research Council.

South Africa. Department of Education. 2002. Revised national curriculum statement. June 2002. [Online]. Available: http:// education.pwv.gov.za/. Accessed 2 I June 2003.

Stilwell, C. \& Bell, F. 2003. Information needs of learners at Emzamweni High School, Inadi, South Africa: a preliminary report on an assessment linked to the CHESP community based learning model. In Zinn, S, Hart G \& Howe, E. Eds. IASL reports 2003: school libraries breaking down barriers. Selected papers from the 32nd Annual Conference of the International Association of School Librarianship and the 7th International Forum on Research in School Librarianship, Durban, South Africa, 7-II July 2003. Seattle: IASL: 332- 343.

Todd, M \& Tedd, L A. 2000. Training courses for ICT as part of lifelong learning in public libraries: experiences with a pilot scheme in Belfast public libraries. Program, 34(4): 375-383.

Todd, R. 1995. Information literacy: a sensemaking approach to learning. In Booker, D. Ed. The learning link: information literacy in practice. Adelaide: Auslib Press: 17-26.

Todd, R. 2004. Adolescents of the information age: patterns of information seeking and use, and implications for information professionals. School libraries worldwide, 9(2): 27-46.

Van Helden, P \& Lor, P J. 2002. Public and community libraries inventory of South Africa: PACLISA final report. Pretoria: National Library of South Africa. 